\title{
Unnatural Womanhood: Moral Treatment, Puerperal Insanity and the Female Patients at the Fremantle Lunatic Asylum, 1858-1908
}

Alexandra Wallis

University of Notre Dame Australia

\begin{abstract}
Puerperal insanity, or what might be understood as a form of postnatal depression, was the third most frequent diagnosis among the women of the Fremantle Lunatic Asylum from 1858 to 1908 . The emphasis society placed on pregnancy and child-rearing as women's primary function resulted in anxieties surrounding childbirth. Modern medical professionals are now aware there are several factors involved in postnatal depression. However, nineteenth-century physicians viewed it as a common issue of 'mental derangement' in women soon after childbirth, but unlikely to be permanent. To treat this, Fremantle Asylum physicians instituted moral treatment methods, including domestic work as rehabilitation. As this paper demonstrates, this form of rehabilitation reinforced the conventional feminine behaviours essential for functioning wives and mothers in nineteenth- and early twentieth-century society. As women suffering puerperal insanity challenged the notions of domesticity and femininity, their experiences allow for an analysis of how moral treatment was implemented in Fremantle. Through the patient records and case books of the Fremantle Asylum, this paper reveals that moral treatment did not cure all patients, leaving some susceptible to readmission and continued mental illness.
\end{abstract}


Alice Mary Anderson was a 27-year-old Roman Catholic housewife admitted to the Fremantle Lunatic Asylum on 30 December 1901 diagnosed with 'puerperal melancholia' caused by childbirth and with 'general symptoms of puerperal mania'. ${ }^{1}$ One month before Alice's admission, she had given birth to a daughter, Kathleen Maud. ${ }^{2}$ However, her husband, Charles, reported Alice had threatened to poison herself, and the day before admission 'she attempted to get away to drown herself in the river. She also attempted to take hold of a knife. Later she took her boots off in the street in order that she might walk across broken glass. ${ }^{3}$ In the asylum, Medical Superintendent Dr Sydney Hamilton Rowan Montgomery observed Alice was 'very restless and excited, weeps and bemoans all days, says she is lost forever'. ${ }^{4}$ Eight days later, on 7 January 1902, Montgomery noted that Alice was 'still very depressed' and 'will not speak or employ herself'. ${ }^{5}$ However, towards the end of January, she was 'rather better, has started to do a little sewing' but was 'still depressed'. ${ }^{6}$ Approximately one month later, on 14 February, Montgomery reported that Alice was 'improving, is more cheerful and contented'. 7 By the end of February, Alice was considered convalescent, and on 22 March 1902, she was 'discharged recovered', after three months in the asylum. ${ }^{8}$ Alice's depressed responses after childbirth manifested as suicidal actions that resulted in her committal.

Puerperal insanity was a nineteenth-century understanding of postnatal depression, although not understood or treated as it is today. ${ }^{9}$ It was not uncommon for a diagnosis to include both puerperal melancholia and

1 Thanks to my supervisor Leigh Straw for her advice and support, Deborah Gare, Joan Wardrop and the Notre Dame postgraduate crew for their encouragement and feedback, in particular, to Toni Church for her comments on this article. I would also like to acknowledge the State Records Office of Western Australia (SROWA) for their assistance in accessing records. This research has been carried out with the aid of an Australian Postgraduate Award (APA). SROWA: Case Book Female Patients, 1901-08, Folio 13, 30 December 1901.

2 Ibid.; The Births, Deaths, and Marriages Index of Western Australia (BDMWA): Certificate of Birth, Kathleen Maud Anderson (1543/1901).

3 Certificate of Birth, Kathleen Maud Anderson (1543/1901).

4 SROWA: Case Book Female Patients, Folio 14, 30 December 1901. Dr Montgomery was Medical Superintendent 1901-08.

5 Ibid., 7 January 1902

6 SROWA: Case Book Female Patients, Folio 14, 21 January 1902.

7 Ibid., 14 February 1902.

8 Ibid., 28 February; 22 March 1902.

9 A direct comparison between puerperal insanity and postnatal depression is not overly beneficial; this paper does not intend to retrospectively diagnose the women of Fremantle. 
puerperal mania, as the words were used interchangeably. ${ }^{10}$ Puerperal mania was the most common form of puerperal insanity found in asylums and was an acute and sudden onset of mania. ${ }^{11}$ The treatment for Alice was similar to that of the other women admitted to the Fremantle Lunatic Asylum: moral treatment. Alice was prescribed the domestic task of sewing, which she initially refused to do, although she eventually took well to the task. Alice was a success of moral treatment as her behaviour was perceived to be improved and she had regained some sanity through the domestic tasks. However, Alice's case also reveals that although she was discharged, she may still have been suffering from various mental illnesses and quite possibly did not receive adequate help for her situation.

This paper will examine the implementation of moral treatment in the Fremantle Lunatic Asylum from 1858 to 1908, through the cases of the women admitted with puerperal insanity. ${ }^{12}$ The examination of the female patient records will reveal that moral treatment reinforced nineteenthand early twentieth-century gender expectations for women through domestic chores and socially appropriate behaviours for women. Thus, the analysis of puerperal insanity patients determined the underdeveloped institutional and social understandings of postnatal depression in colonial Fremantle. The paper concludes that while moral treatment and domestic rehabilitation provided useful chores for women in the asylum, this method alone failed to provide the help that the women needed or to treat underlying psychological issues. Thus, it left women vulnerable to readmission and the potential for continued mental illness.

This research will contribute to existing historical scholarship on puerperal insanity and moral treatment, to aid in understandings in the development of attitudes and treatment methods regarding postnatal depression. The paper is shaped by wider research into the experiences of the female patients at the Fremantle Lunatic Asylum. As such, this paper provides original data on puerperal insanity and adds analysis of Fremantle Asylum patient notes to gendered Australian asylum historical scholarship.

10 I Loudon, 'Puerperal Insanity in the 19th century', Journal of the Royal Society of Medicine, 81 (1988): 76.

11 Ibid. See Table 1.1 for details of Fremantle asylum diagnosis.

12 SROWA: Case Book Female Patients, 1878-97; AU WA S2219, Cons 2724 03; Case Book Female Patients, 1901-08; AU WA S2219 Cons 3100 01; Case Book Female Patients, 1906-08; AU WA S2219 Cons 2724 04; Case Book Female Patients Chronic Medical Conditions, 1901-08; AU WA S2219, Cons 3103 01; Female Register Fremantle Lunatic Asylum Case Book, 1873-78; AU WA S2219, Cons 5759 1; Register of Female Patients, 1858-73; AU WA S507, Cons 1120 04. These dates have been selected according to the time the asylum was in operation in Fremantle. 


\section{Moral Treatment}

Inspired by the Enlightenment, nineteenth-century physicians began to revolutionise asylum treatment. The development from this period was moral treatment. Moral treatment originated in England when William Tuke founded the York Retreat in 1796. The founder's grandson Samuel Tuke wrote in 1813 that intellectual, active, and moral power, are usually rather perverted than obliterated' in cases of insanity; with moral instruction, they could be cured. ${ }^{13}$ Moral treatment aimed to enforce 'good' habits in patients to teach them how to be good citizens; therefore the asylum had to reinforce skills according to gender, including social norms and work. ${ }^{14}$ Louise Hide notes that moral treatment was seen as an advancement in humanitarian asylum treatment. ${ }^{15}$ However, as Michel Foucault argued, moral treatment 'symbolized the massive structures of bourgeois society in its values. ${ }^{16}$ Thus, Foucault saw moral treatment as moral imprisonment. ${ }^{17}$

In colonial Western Australia, moral treatment governed asylum methods. ${ }^{18}$ The Fremantle Lunatic Asylum was constructed from 1861 and opened in $1865 .{ }^{19}$ Although designed for the Fremantle community, the asylum was at capacity ( 28 men and 17 women) when it officially opened..$^{20}$ These admission numbers were a sign of chronic overcrowding in Fremantle, which was a constant complaint in the medical superintendent's annual reports. ${ }^{21} \mathrm{~A}$ common issue for physicians who implemented moral treatment was overcrowding. Overcrowding created

13 Samuel Tuke, A Description of the Retreat: An Institution Near York for Insane Person of the Society of Friends (London: Dawson, 1813), 134.

14 Elaine Showalter, The Female Malady: Women, Madness and English Culture 1830-1980 (London: Virago Press, 1987), 31.

15 Louise Hide, Gender and Class in English Asylums, 1890-1914 (Hampshire: Palgrave Macmillian, 2014).

16 Michel Foucault, Madness and Civilization: A History of Insanity in the Age of Reason, trans. Richard Howard (Oxon: Routledge, 2001), 260.

17 Suzanna M Peloquin, 'Moral Treatment: Contexts Considered', The American Journal of Occupational Therapy, 43, no. 8 (1989): 524.

18 Indigenous peoples are the traditional custodians of Western Australia with a history spanning 40,000-60,000 years and the Whadjuk Noongar are custodians of the land in Fremantle.

19 Jane Hall, May They Rest in Peace: The History and Ghosts of the Fremantle Asylum (Carlisle, WA: Hesperian Press, 2013), v-5. The Harbourmaster Daniel Scott's warehouse was used as a temporary asylum from 1857 , admitting women from 1858 . These patients were transferred to the permanent building from 1864 .

20 Hall, May They Rest in Peace, 6.

21 Ibid. The difference in male and female population demographics during this period could account for the male patients usually outnumbering the female patients. 
difficulties in providing individualised care, and leisure rooms were used as sleeping quarters. ${ }^{22}$ Thus, Fremantle sometimes struggled to institute moral treatment ideals.

The first of the Fremantle medical superintendents, Dr George Attfield, emphasised human nature in the care for the mentally ill. ${ }^{23}$ In order to implement moral treatment he supplied amusements such as books, ball games and draughts in the evening. ${ }^{24}$ However, under his care, women's amusement constituted washing, sewing and housework. ${ }^{25}$ Female patients were not forbidden to engage with those amusements; nevertheless, domestic tasks were the primary amusements for women. The succeeding medical superintendent, Dr Henry Calvert Barnett, created Rules for the Guidance of Attendants (1872), which embraced the idea of moral care and emphasised the notions of 'Gentleness, Firmness, Tolerance'. ${ }^{26}$ Barnett's rules reflected moral treatment techniques: patients were to be employed and active, and attendants were not to use physical intimidation or harm in their overall humane treatment of patients. ${ }^{27}$ In his 1889 report, Barnett wrote that 'the male patients are occupied in gardening, cutting firewood, pumping water, cooking, cleaning the premises, etc., and the women do all the washing, and make their own clothing'. ${ }^{28}$ Thus, medical superintendents made a clear link between women's amusement and domestic chores.

To examine the use of moral treatment in Fremantle, this paper analyses a particularly gendered experience of madness: puerperal insanity. Nineteenth-century physicians believed that childbirth had links to insanity. ${ }^{29}$ In 1835, Dr James Cowles Prichard argued that puerperal madness was a form of mental 'derangement' in women soon after childbirth, and it would often end in death or the quick recovery of

22 Peloquin, 'Moral Treatment', 542.

23 Phil Maude, 'Treatment of Western Australia's Mentally Ill During the Early Colonial Period, 1826-1865', Australasian Psychiatry, 21, no. 4 (2013): 400-1, doi.org/10.1177/1039856213492863. Dr Attfield was Medical Superintendent from 1858-70.

24 Maude, 'Treatment of WA Mentally Ill', 400.

25 Ibid.

26 Philippa Martyr, 'Unlikely Reformer: Dr Henry Calvert Barnett (1832-1897)', Australasian Psychiatry, 25, no. 5 (2017): 498, doi.org/10.1177/1039856217715992. Dr Barnett was Medical Superintendent 1872-97.

27 Henry Calvert Barnett, Rules for the Guidance of Attendants, Fremantle Lunatic Asylum, 1872, Lunatics (Folios 12-106), SROWA, AU WA S2941-cons36, item 721.

28 Henry Calvert Barnett, Report Upon the Lunatic Asylum at Fremantle, for the Year 1889, by the Surgeon Superintendent (Perth: Richard Pether, Government Printer, 1890), 5.

29 Loudon, 'Puerperal Insanity', 76. 
reason. ${ }^{30}$ Hilary Marland writes that physicians recognised puerperal insanity as so common that it was almost an 'anticipated accompaniment of the process of giving birth'. ${ }^{31}$ James De Burgh Griffith, medical officer at Yarra Bend Asylum, Victoria, wrote in 1882, 'I do not know anything more alarming to a family circle, or more trying to the medical attendant. All that seemed bright has suddenly become changed, and instead of joy there has come unmeasured trouble. ${ }^{32}$ Therefore, hospitals did not always have the time or facilities to treat these patients, and they were sent to asylums. However, Griffith added that 'the friends of the patient shrink from the idea of sending her to an asylum for the insane, and indeed, will endure such trouble before they adopt such a course'. ${ }^{33}$ Griffith, and others, believed puerperal insanity could be well treated at home, thus those women sent to asylums were very unwell or even violent. ${ }^{34}$

The women who were diagnosed with puerperal insanity were perceived by medical professionals and society as the opposites of 'good' women, rejecting or struggling with the important role of motherhood. Jill Julius Matthews argues, in her study of the Glenside Hospital in South Australia during the twentieth century, that case notes revealed some women had 'suffered no illness till after the birth of a child'. ${ }^{35}$ Whether their mental illness was perceived to be directly caused or exacerbated by parturition, moral treatment was applied to these women. Morag Allan Campbell notes that a focus on puerperal insanity patients can obscure the fact that all female patients were expected to adhere to the ideal female role. ${ }^{36}$ Moral treatment in Fremantle was not exclusive to puerperal patients and was used across all diagnoses and genders. ${ }^{37}$ However, women diagnosed with puerperal insanity offer a unique insight into the gendered experience of diagnosis and treatment in a nineteenth-century asylum.

30 James Cowles Prichard, A Treatise on Insanity and Other Disorders Affecting the Mind (London: Sherwood, Gilbert, and Piper, 1835), 306, doi.org/10.1037/10551-000.

31 Hilary Marland, Dangerous Motherhood: Insanity and Childbirth in Victorian Britain (Hampshire: Palgrave Macmillan, 2004), 5.

32 James De Burgh Griffith, 'Puerperal Insanity', Australian Medical Journal, iv, no. 6 (June 1882): 241.

33 Ibid.

34 Ibid.

35 Jill Julius Matthews, Good and Mad Women: The Historical Construction of Femininity in Twentieth Century Australia (North Sydney, NSW: George Allen \& Unwin Publishers, 1984), 178.

36 Morag Allan Campbell, "Noisy, Restless and Incoherent": Puerperal Insanity at Dundee Lunatic Asylum', History of Psychiatry, 28, no. 1 (2017): 54, doi.org/10.1177/0957154x16671262.

37 Moral treatment in the Fremantle Asylum is examined in greater detail in the author's PhD thesis. 


\section{Puerperal Patients in the Fremantle Lunatic Asylum}

In Fremantle, 62 women were admitted to the asylum for puerperal insanity. As seen in Table 1.1, the total number of puerperal insanity patients admitted was 13.7 per cent of the total asylum population from 1858 to 1908 (452 patients in total). ${ }^{38}$ The context of all female admissions to Fremantle reveals that the most frequent recorded diagnosis was delusions at 24 per cent, 19 per cent with mania, 12.4 per cent with dementia and 10.8 per cent with melancholia. Thus, puerperal insanity was the third-highest identified reason for admission to the Fremantle Asylum. On admission there were often different terms used for diagnosis resulting in 73 terms written into the case books. The many terms could be due to the fact that puerperal insanity was, at times, a convenient diagnosis for women, with physicians eager to find labels that were applicable for their patients. ${ }^{39}$ Joan Busfield argues that the category was imprecise and often referred to anything from pregnancy to years after confinement. ${ }^{40}$ Thus, in Fremantle, different puerperal terms were used interchangeably.

Table 1.1: Puerperal Insanity Terms Used on Admission to the Fremantle Lunatic Asylum (1858-1908)

\begin{tabular}{|l|r|r|r|r|r|r|r|r|}
\hline & $\mathbf{1 8 5 8 -}$ & $\mathbf{1 8 7 3 -}$ & $\mathbf{1 8 7 8 -}$ & $\mathbf{1 9 0 1 -}$ & $\mathbf{1 9 0 1 -}$ & $\mathbf{1 9 0 6 -}$ & Total & \% \\
\hline Puerperal mania & 1 & 1 & 5 & - & 12 & 7 & $\mathbf{2 6}$ & $\mathbf{4 2 \%}$ \\
\hline Pregnancy & 2 & 1 & - & - & 4 & 2 & $\mathbf{9}$ & $\mathbf{1 4 . 5 \%}$ \\
\hline Lactation & - & - & 1 & 1 & 5 & 1 & $\mathbf{8}$ & $\mathbf{1 3 \%}$ \\
\hline Miscarriage & - & - & - & - & 4 & 3 & $\mathbf{7}$ & $\mathbf{1 1 . 3} \%$ \\
\hline Death of children & - & - & - & - & 2 & 2 & $\mathbf{4}$ & $\mathbf{6 . 4 \%}$ \\
\hline Childbirth & - & - & - & - & 2 & 2 & $\mathbf{4}$ & $\mathbf{6 . 4 \%}$ \\
\hline $\begin{array}{l}\text { Attempted harm } \\
\text { of child }\end{array}$ & - & - & 2 & - & 1 & - & $\mathbf{3}$ & $\mathbf{4 . 8} \%$ \\
\hline Abortion & - & - & - & - & 2 & - & $\mathbf{2}$ & $\mathbf{3 . 2} \%$ \\
\hline $\begin{array}{l}\text { Puerperal } \\
\text { melancholia }\end{array}$ & - & - & - & - & 2 & - & $\mathbf{2}$ & $\mathbf{3 . 2} \%$ \\
\hline
\end{tabular}

38 These statistics are based on the SROWA sources and the dates listed correspond to the case books: see footnote 13 . The percentages for Table 1.1 are the total number of admissions that relate to puerperal insanity.

39 Marland, Dangerous Motherhood, 105.

40 Joan Busfield, Men, Women and Madness: Understanding Gender and Mental Disorder (London: MacMillan Press Ltd, [1996] 2005), 159. 


\begin{tabular}{|c|c|c|c|c|c|c|c|c|}
\hline & $\begin{array}{c}1858- \\
1873\end{array}$ & $\begin{array}{c}1873- \\
1878\end{array}$ & $\begin{array}{c}1878- \\
1897\end{array}$ & $\begin{array}{c}1901- \\
1908\end{array}$ & $\begin{array}{l}1901- \\
1908\end{array}$ & $\begin{array}{c}1906- \\
1908\end{array}$ & Total & $\%$ \\
\hline Puerperium & - & - & - & - & 1 & - & 1 & $1.6 \%$ \\
\hline Premature baby & 1 & - & - & - & - & - & 1 & $1.6 \%$ \\
\hline Infanticide & 1 & - & - & - & - & - & 1 & $1.6 \%$ \\
\hline Puerperal insanity & - & - & 1 & - & - & - & 1 & $1.6 \%$ \\
\hline $\begin{array}{l}\text { Neglect of nurse } \\
\text { in confinement }\end{array}$ & - & - & - & - & - & 1 & 1 & $1.6 \%$ \\
\hline Postpartum & - & - & - & - & - & 1 & 1 & $1.6 \%$ \\
\hline $\begin{array}{l}\text { Demented after } \\
\text { confinement }\end{array}$ & - & - & 1 & - & - & - & 1 & $1.6 \%$ \\
\hline Not herself after birth & - & - & - & - & - & 1 & 1 & $1.6 \%$ \\
\hline $\begin{array}{l}\text { Total times } \\
\text { terms used }\end{array}$ & 5 & 2 & 10 & 1 & 35 & 20 & 73 & - \\
\hline $\begin{array}{l}\text { Total number of } \\
\text { women admitted for } \\
\text { puerperal reasons }\end{array}$ & 5 & 1 & 10 & 1 & 27 & 18 & 62 & $13.7 \%$ \\
\hline
\end{tabular}

Note: The percentages are based on the total number of women admitted for puerperal reasons. However, the $13.7 \%$ figure is based on the total number of female patients admitted across 1858 to 1908.

Source: Author's research.

The individuals who admitted the 62 women included those with a professional responsibility for the patient and those with a personal relationship, as seen in Table 1.2. The majority, 69.3 per cent, were admitted by professionals including doctors, regional magistrates or Justices of the Peace. Another 30.6 per cent were admitted by their male relatives, of which 26 per cent were their husbands. These statistics are consistent with the general female patient statistics in which most women were also admitted by professionals at 61.5 per cent, and 19 per cent were admitted by a male relative, of which 11.7 per cent were husbands. This reveals that admission of women with puerperal insanity to the Fremantle Asylum was decided amongst male professionals and male family members.

Table 1.2: Persons Who Admitted Female Patients to the Fremantle Lunatic Asylum (1858-1908)

\begin{tabular}{|l|r|r|r|r|r|r|r|r|r|}
\hline & $\begin{array}{c}\text { Drs/ } \\
\text { RM/JP }\end{array}$ & Husband & $\begin{array}{c}\text { Medical } \\
\text { Board }\end{array}$ & Brother & Son & Father & Friend & Mother & N/A \\
\hline Total & 43 & 16 & 2 & 1 & 1 & 1 & 1 & 1 & 1 \\
\hline$\%$ & $69.3 \%$ & $26 \%$ & $3.2 \%$ & $1.6 \%$ & $1.6 \%$ & $1.6 \%$ & $1.6 \%$ & $1.6 \%$ & $1.6 \%$ \\
\hline
\end{tabular}

Note: If admitted twice by the same person it was counted once.

Source: Author's research. 
The patient registers and case books from 1858 to 1908 also provide a greater picture of the kinds of women that were admitted to the asylum, through their age, marital status, religious denomination, occupation and nationality. As puerperal insanity was a postpartum mental illness, it is no surprise that the women who were admitted were of childbearing age, most were aged between 20 to 39 years old (76 per cent). ${ }^{41}$ This statistic is slightly higher than the general female asylum age range (which was 55.5 per cent for those between 20 and 39), although this was still the highest category.

The marital status of the women admitted for puerperal reasons is evidenced in Table 1.3. This data reveals that women admitted for puerperal reasons were overwhelmingly married, at 87 per cent. However, overall, married women constituted only 45 per cent of all female patients admitted from 1858 to $1908 .{ }^{42}$ Thus, it can be suggested that more married women were identified as having puerperal symptoms than single women. Pat Jalland notes that in colonial Australia many convicts and early migrants were obliged to confront illness and destitution without the support of family networks or traditional communities, until new family formation took place over generations. ${ }^{43}$ The lack of familial support would be further isolating for single mothers. It is also possible that single mothers perhaps received different diagnoses that were not associated with puerperal insanity as they may have kept their pregnancies secret.

Table 1.3: Marital Status of Puerperal Patients in Fremantle Lunatic Asylum (1858-1908)

\begin{tabular}{|l|r|r|r|r|r|r|}
\hline & \multicolumn{1}{|c|}{ Married } & \multicolumn{1}{c|}{ Single } & \multicolumn{1}{|c|}{ Widow } & $\begin{array}{l}\text { Married/ } \\
\text { Widow }\end{array}$ & $\begin{array}{l}\text { Single/ } \\
\text { Married }\end{array}$ & \multicolumn{1}{c|}{ N/A } \\
\hline Total & 54 & 2 & 1 & 1 & 2 & 2 \\
\hline$\%$ & $87 \%$ & $3.2 \%$ & $1.6 \%$ & $1.6 \%$ & $3.2 \%$ & $3.2 \%$ \\
\hline
\end{tabular}

Note: Married/Widow = Married then later noted as widowed in a readmission. Single/ Married $=$ Single and then later noted as married in a readmission.

Source: Author's research.

41 Total percentages for the age of puerperal patients on admission: 10-19 (1.6 per cent), 20-29 (46.7 per cent), 30-39 (29 per cent), 40-49 (7.7 per cent), 50-59 (3.2 per cent), unknown (1.6 per cent).

42 Marital status of all female patients from 1858 to 1908: married 45 per cent, single 24.5 per cent, widowed 8.8 per cent, married/widowed 1.3 per cent, single/married 0.88 per cent, and 19.5 per cent were unknown.

43 Pat Jalland, Old Age in Australia: A History (Melbourne: Melbourne University Press, 2015). 
Table 1.4 details the various religious denominations of the women admitted for puerperal reasons, of which Protestant faiths were the most frequent at 55 per cent. This statistic is also slightly higher than the general statistic for religion, which was 40.5 per cent in total. Thus, religion must not have been a significant factor in admission, as it was reasonably consistent with general female admissions.

Table 1.4: Religious Denominations of Puerperal Patients in Fremantle Lunatic Asylum (1858-1908)

\begin{tabular}{|l|r|r|r|r|r|r|r|}
\hline & $\begin{array}{c}\text { Roman } \\
\text { Catholic }\end{array}$ & $\begin{array}{c}\text { Church of } \\
\text { England }\end{array}$ & Anglican & Presbyterian & Methodist & Wesleyan & N/A \\
\hline Total & 13 & 9 & 11 & 6 & 3 & 4 & 11 \\
\hline$\%$ & $21 \%$ & $14.5 \%$ & $17.7 \%$ & $9.6 \%$ & $4.8 \%$ & $6.5 \%$ & $17.7 \%$ \\
\hline \multicolumn{2}{|l}{ One each was listed for Protestant, Jewish, Catholic, Church of Christ and Baptist. } \\
\hline
\end{tabular}

Source: Author's research.

As detailed in Table 1.5, the occupations for puerperal women were most commonly housewife or housework, with 50 per cent of puerperal patients considered to be housewives. However, 22.6 per cent were also employed beyond the home, most commonly in domestic service. The puerperal patients' statistics are not dissimilar to the general female patients, of which 23.6 per cent were in domestic work and 21 per cent were listed as housewives; a further 47.3 per cent had no occupation identified. However, puerperal patients were identified more as housewives than were general female patients. This is not to say that because these women were mothers they did not also have paid employment; however, it does reveal that it was generally women who were working within their homes, juggling domestic duties and child-rearing, that were admitted to Fremantle for puerperal reasons.

Table 1.5: Occupations Listed for Puerperal Patients in Fremantle Lunatic Asylum (1858-1908)

\begin{tabular}{|l|r|r|r|r|r|r|}
\hline & Housework & Housewife & $\begin{array}{c}\text { Domestic } \\
\text { Service }\end{array}$ & Tailoress & $\begin{array}{l}\text { School } \\
\text { Teacher }\end{array}$ & N/A \\
\hline Total & 17 & 14 & 11 & 2 & 1 & 17 \\
\hline$\%$ & $27.4 \%$ & $22.6 \%$ & $17.7 \%$ & $3.2 \%$ & $1.6 \%$ & $27.4 \%$ \\
\hline
\end{tabular}

Source: Author's research. 
Lastly, the nationalities of the patients were also recorded on admission. As seen in Table 1.6, the largest percentage of women admitted were from Victoria and, overall, most were of Australian origin at 46.7 per cent. $^{44}$ The Australian majority indicates that puerperal patients most likely had stronger family networks, which led to their illness being identified and their incarceration in the asylum.

Table 1.6: Nationalities of Puerperal Patients in Fremantle Lunatic Asylum (1858-1908)

\begin{tabular}{|l|r|r|r|r|r|r|r|r|r|}
\hline & Vic & Colonial & English & WA & Irish & SA & British & Scottish & N/A \\
\hline Total & 16 & 7 & 5 & 2 & 2 & 2 & 2 & 2 & 21 \\
\hline$\%$ & $26 \%$ & $11.3 \%$ & $8 \%$ & $3.2 \%$ & $3.2 \%$ & $3.2 \%$ & $3.2 \%$ & $3.2 \%$ & $34 \%$ \\
\hline
\end{tabular}

Source: Author's research.

Interestingly, of the 62 puerperal patients, 38 (61.3 per cent) were discharged from the asylum at some point, as seen in Table 1.7. Overall, most of the women admitted were later transferred to Claremont (35.5 per cent), were discharged just once (32.3 per cent), with another 13 per cent discharged multiple times, or died in the asylum (19.3 per cent). ${ }^{45}$ These statistics reveal that most puerperal patients were discharged from the asylum at one time or another. This clearly illustrates that nineteenthcentury physicians believed that puerperal insanity was curable and not a long-term issue. However, of all those discharged, 47.4 per cent were readmitted to the asylum, indicating that despite this attitude, their mental illnesses were often not effectually 'cured' or treated.

Table 1.7: Puerperal Patients Who Were Discharged, Died or Transferred in the Fremantle Lunatic Asylum (1858-1908)

\begin{tabular}{|l|r|r|r|r|}
\hline & \multicolumn{1}{|c|}{$\begin{array}{c}\text { Discharged } \\
\text { Once }\end{array}$} & \multicolumn{1}{c|}{$\begin{array}{l}\text { Discharged } \\
\text { Multiple }\end{array}$} & \multicolumn{1}{c|}{ Died } & Transferred \\
\hline Total & 20 & 8 & 12 & 22 \\
\hline$\%$ & $32.3 \%$ & $13 \%$ & $19.3 \%$ & $35.5 \%$ \\
\hline
\end{tabular}

Note: 38 women were discharged at some point, including the number indicated in the discharged sections of the table and 10 women from the section of those who were later transferred to Claremont $=61.3 \%$ of all puerperal patients.

Source: Author's research.

44 Australian nationality in the patient notes did not include Indigenous women admitted, of which there were five with one woman labelled 'half-caste'.

45 Of those transferred to Claremont, three patients were admitted before 1900, and 19 were admitted from 1900; thus, there was less time for those patients to potentially recover before the move to the Claremont Hospital for the Insane in 1908. 
It is important to note that the patient registers and case books from the Fremantle Lunatic Asylum are potentially problematic resources. The medical superintendents did not always record information consistently, and not every patient has a complete entry. Another factor that should be considered is that they are not written from the perspective of the women; they were written by male medical professionals whose interpretations and diagnoses were influenced by their context. Further, most of the women admitted to Fremantle were illiterate. Literacy was rarely noted in the registers and case books. Dr Attfield made more effort in 1858 to 1872; however, 94 per cent of the women did not have this skill mentioned in their records. Only 10 women were noted to be able to write, eight to read, six for reading and writing, and three were listed as illiterate. Therefore, these patient notes are likely the few remaining sources that provide some understandings of their experiences. Through examining the male medical doctors' notes and assembling new data concerning female patients across the whole period the Fremantle Asylum was in operation, the women admitted for puerperal reasons take greater shape and allow deeper insights into an aspect of their lives. While not personal accounts, they reveal how nineteenth-century colonial physicians categorised and treated women suffering from a gendered form of madness, and thus are invaluable to understandings of the history of mental illness.

\section{Domestic Work and Gendered Madness}

An important feature of moral treatment was to refrain from treating patients inhumanely. A prominent advocate of humane moral treatment was English physician John Conolly who proposed that inmates be allowed the freedom to control their behaviour under the observation of the attendants. ${ }^{46}$ Therefore, nineteenth-century asylums also began to reduce the use of mechanical restraints. ${ }^{47}$ The implementation of this was inconsistent, though most British superintendents did not abolish all forms of restraint. ${ }^{48}$ The irregularity in non-restraint methods in moral

46 Susan Piddock, "The "Ideal Asylum" and Nineteenth-Century Lunatic Asylums in South Australia', in Madness in Australia: Histories, Heritage and the Asylum, eds. Catherine Coleborne and Dolly MacKinnon (Brisbane: University of Queensland Press, 2003), 38.

47 Nancy Tomes, 'The Great Restraint Controversy: A Comparative Perspective on Anglo-American Psychiatry in the Nineteenth Century', in The Anatomy of Madness: Essays in the History of Psychiatry, Vol III: The Asylum and its Psychiatry, eds. William F Bynum, Roy Porter and Michael Shepherd (London: Routledge, 2004), 190, doi.org/10.4324/9781315017112-8.

48 Tomes, 'Great Restraint Controversy', 196. 
treatment was evident in the Australian colonies where the use of restraints persisted, due in part to the colonies' penal origins and their focus on punishment. ${ }^{49}$ Thus, Stephen Garton comments that immediate reform was inhibited by these foundations as well as a general lack of funding. ${ }^{50}$ However, as Peta Longhurst writes, reform in treatment was reflected in improvements in the construction of asylums, and the presence of updated government asylums in New South Wales from at least 1838 reveals an incentive to provide more humane treatment in the Australian colonies. ${ }^{51}$

Work was an essential aspect of moral treatment, it kept patients occupied, which minimised the potential need for the use of restraint. Patient work in psychiatry required routine and acceptance of discipline, which was crucial to re-entering nineteenth-century society. ${ }^{52}$ Therapeutic labour was first introduced into asylums in the 1830s at Conolly's Hanwell Asylum. ${ }^{53}$ Work as rehabilitation was deemed necessary for the 'curable' and convalescent, and was also gradually introduced to the 'chronic' or intellectually disabled patients. ${ }^{54}$ Anne Digby writes that women were the best-occupied patients in the nineteenth century, as it was comparatively easier to employ women in household tasks. ${ }^{55}$ Male patients were taught trades if possible, but they were rarely employed beyond physical labouring in the asylum grounds. ${ }^{56}$ Domestic tasks were deemed unsuitable for men and would not contribute to their recovery. ${ }^{57}$ Conversely, the association between women and domesticity ensured constant employment in the asylum laundry, sewing, knitting, and in self-cleanliness. ${ }^{58}$ As a result, for the female patients domestic tasks were effectively retraining women in expected gender roles.

49 Kenneth C Kirkby, 'History of Psychiatry in Australia, pre-1960', History of Psychiatry, 10, no. 38 (1999): 193, 199, doi.org/10.1177/0957154x9901003802.

50 Stephen Garton, 'Why Asylum Facilities Might Still Be Relevant for Mental Health Care Services Today', Health and History, 11, no. 1 (2009): 33.

51 Peta Longhurst, 'Madness and the Material Environment: An Archaeology of Reform in and of the Asylum', International Journal of Historical Archaeology, 21 (2017): 33, doi.org/10.1007/ s10761-017-0399-0.

52 Waltraud Ernst, 'The Role of Work in Psychiatry: Historical reflections', Indian Journal of Psychiatry, 60, no. 2 (2018): online.

53 Showalter, Female Malady, 40.

54 Anne Digby, 'Moral Treatment at the Retreat, 1796-1846', in The Anatomy of Madness: Essays in the History of Psychiatry, Vol II: Institutions and Society, eds. William F Bynum, Roy Porter and Michael Shepherd (London: Routledge, 2004), 63, doi.org/10.4324/9781315017105-4.

55 Digby, 'Moral Treatment', 63.

56 Lee-Ann Monk, Attending Madness: At Work in the Australian Colonial Asylum (New York: Editions Rodopi BV, 2008), 71.

57 Monk, Attending Madness, 71.

58 Showalter, Female Malady, 79. 
Through these domestic tasks, nineteenth-century physicians reinforced stereotypes of femininity for women who they diagnosed as mentally ill and potentially defying contemporary gender roles. ${ }^{59}$ As Judith Butler states, gender is culturally constructed, and as such women's acceptable behaviour was also created by nineteenth-century society. Butler states that people are only recognised through gender intelligibility; therefore, identity is established through sex and gender, and a person is called into question if they do not act according to that gender. ${ }^{60}$ Anne Summers writes that 'femininity is a cultural imposition upon the female sex, an artificial contrivance designed to replace natural conduct and appearance with conventions which make their governing easier' ${ }^{61}$ Thus, nineteenthcentury Australian society, influenced by British colonialism, had specific expectations of women as wives and mothers. Characteristics for "good" women included quietness, modesty and cautiousness. ${ }^{62}$ Women should preserve the moral values of society, guard her husband's conscience and guide her children. ${ }^{63}$ Penny Russell writes that Australian women's place in respectable society was through her attachment to the home and family. ${ }^{64}$

This construction of gender was also apparent in defining mentally ill behaviours for women and men. Therefore, nineteenth-century Western societies perceived differences in how madness manifested in women and men. During this period, women's insanity could come under the umbrella term 'hysteria', which encompassed varying types of female madness, including religious ecstasy or sexual deviation. ${ }^{65}$ British physicians maintained that a woman's place in society, her role and behaviour were controlled by her reproductive organs. ${ }^{66}$ In 1878 , Bucknill and Tuke wrote that the reproductive organs are frequently

59 Ibid., 86.

60 Judith Butler, Gender Trouble: Feminism and the Subversion of Identity (New York: Routledge, 1990), 10-23.

61 Anne Summers, Damned Whores and God's Police: The Colonisation of Women in Australia (Sydney: NewSouth Publishing, 2016), 367.

62 Andrea Nicki, 'The Abused Mind: Feminist Theory, Psychiatric Disability, and Trauma', Hypatia, 16, no. 4 (2001): 90, doi.org/10.1353/hyp.2001.0060.

63 Sally Mitchell, Daily Life in Victorian England, 2nd ed. (Connecticut: Greenwood Press, 2009), 266.

64 Penny Russell, 'In Search of Woman's Place: An Historical Survey of Gender and Space in Nineteenth-Century Australia', Australasian Historical Archaeology, 11 (1993): 28.

65 Roy Porter, 'The Body and the Mind, the Doctor and the Patient: Negotiating Hysteria', in Hysteria Beyond Freud, ed. Sander L Gilman (Berkley: University of California Press, 1993), 227.

66 Andrew Scull, Hysteria: The Disturbing History (Oxford: Oxford University Press, 2009), 72. 
the seat of disease or abnormal function' ${ }^{67}$ As men's bodies have been the standard by which everything was compared, medical professionals viewed women's bodies, especially pregnant bodies, as dubious or potentially madness-inducing. ${ }^{68}$ Nineteenth-century medical authorities did not solely base their opinions on scientific fact but bent reality to the cultural perceptions and needs of their universe. ${ }^{69}$ Thus, there was a well-established connection between women's bodies and insanity in the nineteenth-century medical community.

The most apparent connection between women's bodies and madness was in puerperal insanity. While puerperal insanity was a unique nineteenthcentury diagnosis, women still suffer from postnatal depression, and there are continued scientific debates of the causes of postnatal mental illness. Modern medical professionals note there are many factors involved in postnatal depression, including hormonal changes, economic and relationship stress, previous traumas and a genetic predisposition to depression. However, nineteenth-century physicians deemed that the 'unusual excitement throughout the nervous system' and their weakened constitution due to pregnancy and childbirth predisposed women to madness. ${ }^{70}$ The combination of 'intestinal irritation, loss of blood and exhaustion' was what contributed to puerperal insanity. ${ }^{71}$ However, Marland argues that in the nineteenth century many women admitted to asylums with puerperal insanity were also unhealthy and suffering other diseases, which could also contribute to their mental state. Thus, it is essential to remember that there were likely women who suffered from some form of postnatal mental illness that did not seek or get help or were not diagnosed with puerperal insanity.

However, the biggest concern for nineteenth-century physicians was that puerperal patients acted outside the bounds of womanhood. Puerperal patients 'challenged notions of domesticity and femininity and flouted ideals of maternal conduct and feeling'..$^{72}$ Nancy Theriot contends that

67 John Charles Bucknill and Daniel Hack Tuke, A Manual of Psychological Medicine Containing the Lunacy Laws, the Nosology, Aetiology, Statistics, Description, Diagnosis, Pathology and Treatment of Insanity, 3rd ed. (Philadelphia: Lindsay and Blakiston, 1874), 595, doi.org/10.1192/ s0368315x00227059.

68 Rebecca Kukla, Mass Hysteria: Medicine, Culture, and Mother's Bodies (Maryland: Rowman \& Littlefield Publishers Inc., 2005), 3.

69 Robert Muchembled, Orgasm and the West: A History of Pleasure from the Sixteenth Century to the Present, trans. J Birrell (Cambridge: Polity Press, 2008), 160.

70 Marland, Dangerous Motherhood, 41.

71 Ibid.

72 Ibid., 5. 
women's indifference or hostility to children or husbands contradicted physicians' notions about women's 'maternal and wifely devotion'. ${ }^{73}$ Therefore, as Theriot argues, puerperal insanity was a socially constructed disease, reflecting both nineteenth-century gender constraints and the professional battles accompanying medical specialisation. ${ }^{74}$ She asserts that whether on a conscious or unconscious level, women who suffered from puerperal insanity were rebelling against the constraints of gender. ${ }^{75}$ Hilary Marland also notes that physicians believed that social, economic and circumstantial situations like poverty, domestic difficulties and 'the despair of motherhood' were causes of puerperal insanity. ${ }^{76}$ Thus, there was an awareness of a connection between the constraints of women's lives and mental illness. As Bronwyn Labrum notes, 'the existence of feminine notions of respectability affirms the importance of gender in studies of madness. ${ }^{77}$ However, female patients in colonial contexts were not labelled as insane only due to their lack of feminine behaviours, and there is no evidence of a fundamental link between women and madness. ${ }^{78}$ Labrum argues that the realities of women's lives and the conditions they lived with their families were equally important factors. ${ }^{79}$ Nevertheless, an analysis of puerperal insanity patients illustrate how nineteenth- and early twentieth-century moral treatment aimed to reinforce gender roles, as these women behaved in opposition to the ideal wife and mother.

\section{'Discharged Recovered': Charlotte and Edith}

In the Fremantle Lunatic Asylum, work was encouraged for all women, including the puerperal patients. However, a reluctance to perform household tasks was punishable, incurring lengthier stays. ${ }^{80}$ As Catharine

73 Nancy Theriot, 'Diagnosing Unnatural Motherhood: Nineteenth-century Physicians and "Puerperal Insanity”, American Studies, 30, no. 2 (1989): 74.

74 Theriot, 'Diagnosing Unnatural Motherhood', 72.

75 Ibid., 81.

76 Hilary Marland, 'Women, Health, and Medicine', in The Oxford Handbook of the History of Medicine, ed. Mark Jackson (Oxford: Oxford University Press, 2011), 491.

77 Bronwyn Labrum, 'Looking Beyond the Asylum: Gender and the Process of Committal in Auckland, 1870-1910', New Zealand Journal of History, 26, no. 2. (1992): 144.

78 Ibid.

79 Ibid.

80 Bronwyn Harman, 'Out of Mind, Out of Sight: Women Incarcerated as Insane in Western Australia 1858-1908' (PhD thesis, University of Western Australia, 1993), 117. 
Coleborne writes, a female patient's refusal to work would be read as a rejection of attempts to 'reform' and 'tame' her. ${ }^{81}$ This attitude was reflected in Fremantle as physicians emphasised a willingness to work, rather than the amount of work completed. ${ }^{82}$ It was the activity itself that was thought to be therapeutic rather than the end product. ${ }^{83}$

In Fremantle, women diagnosed with puerperal insanity would often be 'cured' and sent home after a short amount of time. This theory was based on the belief that puerperal insanity was temporary, though severe, and likely to be curable. ${ }^{84}$ In 1846 , Conolly stated that 'cases of puerperal insanity appear to afford a better prospect of recovery than any other'. ${ }^{85}$ Allan Campbell notes that 'curing the patient meant restoring her to a condition fit for return to home, family and the responsibilities of her role as wife and mother'. ${ }^{86}$ In 1903, Australian asylum superintendent William Beattie Smith stated that 'half the cases recover in four months, and thence onward to the ninth month, with a few recoveries even as late as a couple of years' ${ }^{87}$ This attitude was displayed in Fremantle; patients with puerperal insanity who were willing to undertake domestic tasks would often have short asylum admissions. Table 1.7 shows that 61 per cent of all puerperal patients were discharged. This theory was in operation in Fremantle, as will be explored through the patient notes of Charlotte and Edith. However, a speedy turnaround of puerperal patients into their husband's care did not necessarily result in the patients' 'cure' or indicate that they had received the help they needed.

Charlotte Isabella Lyford was 26 years old when she was admitted on 11 January 1904 with puerperal melancholia caused by childbirth. ${ }^{88}$ She was 'melancholic in demeanour' and had made 'unfounded charges

81 Catharine Coleborne, 'Space, Power and Gender in the Asylum in Victoria, 1850s-1870s', in Madness in Australia: Histories, Heritage, and the Asylum, eds. Catharine Coleborne and Dolly MacKinnon (Brisbane: University of Queensland Press, 2003), 55.

82 Harman, 'Out of Mind, Out of Sight', 117-18.

83 Digby, 'Moral Treatment', 63.

84 Hilary Marland, "'Destined to a Perfect Recovery”: The Confinement of Puerperal Insanity in the Nineteenth Century', in Insanity, Institution and Society, 1800-1914, eds. Bill Forsythe and Joseph Melling (Oxon: Routledge, 1999), 137.

85 John Conolly, 'Description and Treatment of Puerperal Insanity', Lecture XIII: Clinical Lectures on the Principle Forms of Insanity, Delivered in the Middlesex Lunatic Asylum at Hanwell, Lancet 1, 28 March 1846, 349, doi.org/10.1016/s0140-6736(02)89248-0.

86 Allan Campbell, "'Noisy, restless and incoherent"', 54.

87 William Beattie Smith, 'Insanity in its Relations to the Practioner, the Patient, and the State', Intercolonial Medical Journal of Australia, 8, no. 2 (1903): 67.

88 SROWA: Case Book Female Patients, 1901-08, Folio 151, 11 January 1904. 
of unfaithfulness against her husband', William. ${ }^{89}$ Dr Montgomery noted Charlotte was 'very dull and stupid, will not speak when spoken to' and had 'to be forced to eat, will not dress or undress herself'. ${ }^{90}$ However, in March, Charlotte began to improve, she was more cheerful, and her delusions were disappearing. ${ }^{91}$ Her improvement continued in April when she 'started to work', and from then she was considered convalescent. ${ }^{92}$ On 2 May Charlotte was given a month's trial release; however, she was 'discharged recovered' merely two days later, after four months in the asylum..$^{93}$ Thus, Charlotte's improved condition was noted through her cheerful demeanour, less obvious delusions and, importantly, her willingness to work.

Edith Maude Jones was also admitted for a short time. Edith was 19 years old when she was admitted on 5 October 1904 with 'puerperal mania' caused by 'puerperium'. ${ }^{94}$ Edith was noted to be dangerous to her three-week-old child, William Ronald, and her medical certificate stated: 'very incoherent, delusions of persecution, aversion to her child, often to husband', James. ${ }^{95}$ Dr William Blackall noted her mental condition as 'emotional'. ${ }^{96}$ However, by the end of October, Edith was 'very much improved, quite coherent, useful in infirmary, quiet', although she 'still had tendency to emotional laughter' ${ }^{97}$ In November, Blackall reported that Edith's improvement was maintained, 'but the abnormal cheerfulness and lack of desire of discharge persists. ${ }^{98}$ Edith relapsed in early November but by the end of the month she was 'improving again, much more rational, quiet and tidy'. ${ }^{99}$ In December, Blackall wrote again that she 'does not seem anxious to see her infant nor for her discharge'. ${ }^{100}$ However, in January 1905 it was reported that Edith 'remains well, useful but perhaps too cheerful'. ${ }^{101}$ Edith was 'discharged

89 Ibid.

90 Ibid.

91 Ibid., Folio 151-152, 14-28 March 1904.

92 Ibid., 14-28 April 1904.

93 Ibid., 2-4 May 1904.

94 Ibid., Folio 199, 5-9 October 1904.

95 Ibid.; BDMWA: Certificate of Birth, William Ronald (778/1904).

96 SROWA: Case Book Female Patients, 1901-08, Folio 199, 5-9 October 1904. Blackall was medical officer to Dr Montgomery from 1904-08.

97 Ibid., 27 October 1904.

98 Ibid., 3 November 1904.

99 Folio 199, 5-9 October 1904, 8-25 November 1904.

100 Ibid., 8 December 1904.

101 Ibid., 5 January 1905. 
recovered' on 12 January after three months in the asylum. ${ }^{102}$ The asylum staff considered Edith's work in the asylum infirmary, likely to be cleaning or laundry, to be a vast improvement, although they noted her disinterest in her child was concerning.

Both Charlotte and Edith were discharged after short asylum admissions. They were considered well enough for discharge when they began to show signs of improvement through the moral treatment methods of domestic chores as rehabilitation. Marland writes that many women may have seen the diagnosis of puerperal insanity and the treatment as a possible respite from the household and maternal duties. ${ }^{103}$ While it may have been a break from the children, especially in Edith's case, the treatment emphasised domestic duties to ready them for the home. Other factors may have led to Charlotte's and Edith's discharges, possibly even time. O'Hara and McCabe reported in 2013 that 'postpartum blues' are a common and transient mood disturbance that can often occur three to five days after childbirth, but the postpartum depression (PPD) period varies from four weeks to a year. ${ }^{104}$ However long the period may have lasted, moral treatment aimed to instil 'good' behaviours in women by ensuring they left the asylum able to fulfil their role as a wife and mother. As will be explored in the following cases of Catherine and Flora, however, the short asylum admissions and moral treatment methods did not necessarily result in a cure.

\section{'Puerperal Mania': Catherine Blackmore}

One of the first women Fremantle physicians diagnosed and recorded as suffering with puerperal mania was Catherine Blackmore. Catherine was a 29-year-old Catholic wife of a York farm labourer, Patrick, when she was admitted with 'puerperal mania' on 26 January $1863 .{ }^{105}$ Catherine had been sent from Perth on the certificate of Drs Ferguson and Poulton after spending three months under treatment in the Perth Hospital and the Perth Poor House. ${ }^{106}$ The admission entry revealed that 'some

102 Ibid., 12 January 1905.

103 Marland, Dangerous Motherhood, 142.

104 Michael W O'Hara and Jennifer E McCabe, 'Postpartum Depression: Current Status and Future Directions', Annual Review of Clinical Psychology, 9 (2013): 381-2.

105 SROWA: Register of Female Patients, 1858-73, Folio 60, 26 January 1863. Catherine's name was also recorded as Caroline and Mary. York is a small wheatbelt town, 97 kilometres from Perth. 106 Ibid. 
symptoms of deranged intellect showed themselves soon after her last confinement (about four months ago) the peculiar symptoms however are not known'. ${ }^{107}$ The Births, Deaths, and Marriages Index of Western Australian reveals that in 1862, Catherine gave birth to her fourth child, Samuel; she had also lost her second baby, James, in 1859, at 10 months old. ${ }^{108}$ Catherine's mental state may have been impacted by having another baby after her son's death. While in the asylum, and not noted in her records, Samuel died at six months old in March, two months after her admission. ${ }^{109}$ Catherine's patient notes, written by Dr Attfield, stated that she was 'of sullen disposition and sometimes violent', and that she had 'rather a wild haggard unsettling look'. ${ }^{110}$ Although she seemed to comprehend questions, she would not answer the physicians. ${ }^{111}$

Catherine was not reported on again for three months, when in April Attfield noted anomalies in her menstruation. Eighteenth- and nineteenth-century doctors regarded puberty as the most psychologically dangerous period of the female life cycle, believing that menstrual discharge predisposed women to insanity. ${ }^{112}$ In Catherine's patient notes Attfield wrote, 'very little alteration has taken place', she had 'menstruated twice since admission but very scantily. ${ }^{113} \mathrm{He}$ also reported that she was 'sometimes very willing to do any work in washing and cleaning, always dresses herself'. ${ }^{114}$ By June, Catherine was recorded as having 'a less downcast look and is more prompt and ready when spoken to' but would still not answer questions and menstruated irregularly. ${ }^{115}$ In August, Attfield wrote that she 'does any kind of work in cleaning, washing and scrubbing to which she is put'; however, she was 'as taciturn and moody as when she first came', and her catamenia was now absent. ${ }^{116}$ Thus, the concern over Catherine's menstrual cycle was evident in the patient records, and it continued to be tracked and noted into 1864 .

107 Ibid.

108 Ibid. Catherine had five children across 1856-68; BDMWA: Certificate of Birth: Mary Jane (3470/1856), James (4213/1858 - d. 1208/1859), Thomas (5053/1860), Samuel (6575/1862 d. 2142/1863), Katherine Elizabeth (10549/1868).

109 SROWA: Register of Female Patients, 1858-73, Folio 60, 26 January 1863.

110 Ibid.

111 Ibid.

112 Showalter, Female Malady, 56.

113 SROWA: Register of Female Patients, 1858-73, Folio 60, 27 April 1863.

114 Ibid.

115 Ibid., 16 June 1863.

116 Ibid., Folio 62, 19 August 1863. 
Despite the physicians' concerns over menstruation, Catherine's willingness to work was positively reported. By April 1864, Attfield commented that Catherine was 'always willing to any work that is set her'. ${ }^{117}$ In July, Catherine's husband and child visited her in the asylum, it had been over a year since she had seen them. ${ }^{118}$ She was reported to have recognised them 'but would not speak a word to them. She does not however fret.' ${ }^{119}$ In September, Attfield noted that 'catamenia now regular, looks wonderfully improved in health, but can hardly be induced to speak'. ${ }^{20}$ This behaviour was maintained and, in October 1865, Patrick applied 'to the Governor to be allowed to take his wife home'; Catherine was noted as 'improved but not sane'. ${ }^{121}$ Attfield wrote that 'her husband having promised to keep supervision over her and treat her kindly was allowed to take her home'. ${ }^{122}$ Therefore, the combination of improved menstruation and willingness to work was acknowledged as an improvement, although not a complete cure.

However, Catherine's 'improved' mental state did not last. On 24 October 1895, 30 years after her discharge, Catherine was readmitted, a 70-yearold 'semi-imbecile' reported as 'harmless and silent'. ${ }^{123}$ At the same time, Catherine's daughter Elizabeth Blackmore was also sent from Katanning by the same physician, Dr Adam. ${ }^{124}$ Elizabeth was a 27-yearold with 'dementia'; Dr Barnett noted 'these hereditary cases are usually hopeless'. ${ }^{125}$ Heredity was especially considered in cases of puerperal insanity: if the family was insane, it was considered a 'predisposition' to mental unbalance. ${ }^{126}$ Catherine spent the rest of her life in the asylum and died on 18 January 1899 aged $74 .^{127}$

Catherine's case reveals the moral treatment methods in Fremantle and also the impact that mental illness could have intergenerationally. Catherine's treatment in the asylum was based on the moral treatment

117 Ibid., Folio 62, 15 April 1864.

118 Ibid., 19 July 1864.

119 Ibid.

120 Ibid., 12 September 1864.

121 Ibid., Folio 83, 2 October 1865.

122 Ibid.

123 SROWA: Case Book Female Patients, 1878-97, Folio 182, 24 October 1895.

124 SROWA: Case Book Female Patients, 1878-97, Folio 182, 24 October 1895.

125 Ibid., Folio 183, 8 November 1895. Elizabeth was discharged to her sister Mary Jane Bradbury in March 1896. She was readmitted in August with 'suicidal insanity', and discharged in January 1897.

126 Theriot, 'Diagnosing Unnatural Motherhood', 77.

127 SROWA: Female Occurrence and Daily Strength Book, 1895-1901, Folio 436, 18 January 1899. 
methods of domestic chores. Her ability and willingness to complete the tasks garnered positive reports, though her irregular menstrual cycle was believed to worsen her condition. Catherine's case reveals that although the asylum staff were aware that she was not completely 'sane', husbands would be granted their wives' discharge if their improvement through domestic tasks was deemed good enough for release. Thus, nineteenthcentury physicians determined that sane behaviour for women was competency in domestic work and the ability to care for their family.

\section{'Puerperal State': Florence 'Flora' Mary Brown}

On 27 September 1903, Florence 'Flora' Mary Brown, a 30-year-old Presbyterian housewife from Kalgoorlie, was admitted to the asylum by her husband Adam in a 'puerperal state' after the birth of her daughter, Mary Florence. ${ }^{128}$ Flora was diagnosed with puerperal mania and described as 'thin and emaciated, brown hair, blue eyes' with a wild manner, 'excited and restless, refuses food, is destructive and at times violent. Scratches and bites. ${ }^{129}$ In October, Dr Montgomery reported Flora to be 'very dull and stupid' and 'will not employ herself'; by November she was still noted as 'continually lazy'. ${ }^{130}$ However, by June 1904 Flora was 'much better, is sewing and seems to take more interest in things'. ${ }^{131}$ In September, Dr Blackall reported that Flora 'varies a great deal between fairly normal mental stability and distinct insanity, she has lately maintained her improved condition for a longer time than normal'. ${ }^{132}$ Consequently, on 23 September, Flora was 'discharged relieved to care of husband'. ${ }^{133}$ Despite Flora's fluctuating mental state, Blackall believed she was well enough to undertake domestic chores at home, which would enable her to care for her family.

128 SROWA: Case Book Female Patients, 1901-08, Folio 121, 27 September 1903; BDMWA: Certificate of Birth, Mary Florence (1701/1903). Kalgoorlie is a Goldfields town 595 kilometres north-east of Perth.

129 SROWA: Case Book Female Patients, 1901-08, Folio 121, 27 September 1903.

130 SROWA: Case Book Female Patients, 1901-08, Folio 121, 7-14 October; SROWA: Case Book Female Patients, 1901-08, Folio 121, 28 November 1903.

131 Ibid., Folio 122, 3 June 1904.

132 Ibid., 5 September 1904.

133 Ibid., 23 September 1904. 
However, the following year on 27 September 1905, Flora was readmitted with melancholia of lactation due to childbirth: her second child, John Donald, was born two months previously. ${ }^{134}$ In her physical exam, Dr Blackall noted that Flora looked 'ill and worn out', and that she 'has a child 2 months old, both breasts hard and full of milk. Abdomen flaccid and such as would be expected after recent confinement'. ${ }^{135}$ Lactational insanity, also taking manic or melancholic form, was seen by nineteenth-century physicians to exhaust the system and lead to depression. ${ }^{136}$ Physicians also believed it to be curable; removal of the patient from her home and its 'associated distress' would solve her problems. ${ }^{137}$ Lactational insanity was reported to only occur in women with several children, not first-time pregnancies, and indeed this was Flora's second pregnancy. ${ }^{138}$

Flora was also in a similar condition to her arrival just before her discharge. Blackall recorded that she was 'quiet and inclined to be resistive, melancholic appearance, speaks very little' and was suicidal. ${ }^{139}$ Sixteen days later, Blackall reaffirmed that 'she has returned to very much the same condition she was in for months previous to her last discharge, quiet and silent, abstracted, rather resistive, smiles vacantly, can answer coherently'. ${ }^{140}$ On 27 October, Flora 'secreted a knife in her dress "to cut her head off" and was placed on a red ticket, a form of suicide watch. ${ }^{141}$ In November, Blackall reported that there was 'little or no change, chattering to herself all day long "why can't I get out of this place; why was I brought here amongst all these people"'. ${ }^{142}$ By 1908 , Flora had made 'no improvement, full of delusions' and she was transferred to Claremont in June. ${ }^{143}$ Flora's battle with suicidal thoughts was deemed too risky for discharge.

134 Ibid., Folio 289, 27 September 1905; BDMWA: Certificate of Birth, John Donald (1857/1905).

135 SROWA: Case Book Female Patients, 1901-08, Folio 289, 27 September 1905.

136 Marland, Dangerous Motherhood, 26.

137 Ibid.

138 Theriot, 'Diagnosing Unnatural Motherhood', 73.

139 SROWA: Case Book Female Patients, 1901-08, Folio 289, 27 September 1905.

140 Ibid., 12 October 1905.

141 Ibid., 27 October 1905.

142 Ibid., 16 November 1905.

143 Ibid., 24 January; 5 June 1908. Flora's story continues in the Claremont records but they are out of the scope of this project. Further research would provide insights into puerperal admissions in the twentieth century. 
Flora's removal to the asylum after the birth of her first baby lasted 10 months, ending when she began to function well enough to care for her family and household. However, her readmission suggests that her potential psychological issues were not cured or understood as she also suffered at the birth of her next baby. The similar mental state was mentioned in her patient notes, although with varying reasons for admission, they were still connected to childbirth and lactation. Therefore, Flora's inability to handle domestic life after childbirth directly impacted her asylum admission. Flora's case also reveals that despite becoming successful at domestic tasks through moral treatment, the method did not cure all the patients. Flora's readmission suggests she, and possibly others, were susceptible to the same recurrent issues that were seemingly left untreated.

\section{Conclusion}

In nineteenth-century society and in the medical community, puerperal insanity was believed to be the ultimate in female mental weakness, an inability to handle the one job they were supposed to do as women. To treat puerperal insanity, the physicians at the Fremantle Lunatic Asylum, from 1858 to 1908, aimed to incorporate the British innovation of moral treatment and introduced work as rehabilitation. This method utilised and represented the ideal of womanhood: cleaning, caring, quietness.

However, the performance of domestic tasks could lead to recovery without treating potentially deeper psychological issues or providing the women with the help they needed. Thus, nineteenth- and early twentiethcentury physicians were yet to understand the complexities of women's postpartum responses. The willingness or ability to complete domestic tasks did not always translate into a healthy mental state, with women who suffered from puerperal insanity often readmitted to the asylum after they had been discharged.

Using original data assembled from the patient registers and case books of the Fremantle Lunatic Asylum, this paper provides insights into colonial women's experiences with diagnosis and treatment methods. In particular, the analysis of women's experiences with asylum care for puerperal insanity placed the women of Fremantle within the existing historical 
scholarship on gendered asylum experiences. This study reveals the value that nineteenth- and early twentieth-century physicians in Fremantle placed on moral treatment and the importance of female gender roles.

Today, societal myths of motherhood still result in women hiding their postnatal depression symptoms. ${ }^{144}$ Alternatively, if and when women do seek help, others may dismiss their concerns. ${ }^{145}$ However, an Australian study from 2019 reveals that awareness of postnatal depression has improved; although, there is still a lack of understanding regarding mental health during pregnancy and awareness of this impact on fathers. ${ }^{146}$ Therefore, continued research in all academic disciplines contributes to removing stigma and constructing a dialogue on postnatal depression. By understanding how women diagnosed with puerperal insanity were treated in nineteenth- and early twentieth-century asylums, this paper provides greater insights into colonial Fremantle women's lives and provides further context for understanding postnatal responses in women today.

144 Teresa M Twomey and Shoshana Bennett, Understanding Postpartum Psychosis: A Temporary Madness (Westport: Praeger Publishers, 2009), xvi.

145 Ibid., xvi.

146 Terri Smith, Alan W Gemmill and Jeannette Milgrom, 'Perinatal Anxiety and Depression: Awareness and Attitudes in Australia', International Journal of Social Psychiatry, 65, no. 5 (2019): 385, doi.org/10.1177/0020764019852656. 
This text is taken from Lilith: A Feminist History Journal: Number 26, published 2020 by ANU Press, The Australian National University,

Canberra, Australia.

doi.org/10.22459/LFHJ.26.08 